\title{
On the Construction of Harmonious Campus in Colleges and Universities
}

\author{
Chunfu Yang ${ }^{1, a}$, Dongliang Yang ${ }^{2, \mathrm{~b}}$, Weihong $\mathrm{Min}^{3, \mathrm{c}^{*}}$ and Yunping Zhang ${ }^{4, \mathrm{~d}}$ \\ ${ }^{1}$ College of Animal Science and Technology, Jilin Agricultural University, Changchun 130118, China \\ ${ }^{2}$ College of Information and Technology, Jilin Agricultural University, Changchun 130118, China \\ ${ }^{3}$ College of Food Science and Engineering, Jilin Agricultural University, Changchun 130118, China \\ ${ }^{4}$ Financial Department, Jilin Agricultural University, Changchun 130118, China
}

*The.corresponding author: Weihong Min, Professor, female, born in August, 1971, interested in food science.

ayangchunfu197242@163.com, b610557217@qq.com, '65817713@qq.com, d798301739@qq.com

*The corresponding author

Keywords: Harmonious campus; Outlook of scientific development; Construction of colleges and universities; Existing problems; Effective measures

\begin{abstract}
Building a harmonious campus is an integral part of building a harmonious society. It is a need for colleges and universities to adapt to social development implement a people-oriented scientific development concept and cultivate a comprehensive quality of talent. This paper analyzes the necessity of building a harmonious campus from the angle of scientific development view, analyzes the existing problems of harmonious campus construction, and puts forward the effective measures to promote the construction of harmonious campus.
\end{abstract}

\section{Importance of Constructing Harmonious Campus}

Building a Harmonious Campus is the Need to Build a Harmonious Society. Schools are an important part of the whole social system and the place to disseminate knowledge and value system with the important responsibility to cultivating talents for the country and the nation. Besides, it is also an important place to construct spiritual civilization, playing the demonstration and leading role in the construction of a harmonious society. Building a harmonious society has always been the social ideal pursued by people, and a harmonious society should be one which is democratic, fair and just with integrity and fraternity, full of vitality, stability and order, and people and nature get along with each other harmoniously. These basic characteristics are interrelated and interacting, and need to be fully grasped and embodied in the process of building a well-off society in an all-round way. Campus harmony is an important aspect of realizing social harmony, reflecting some basic characteristics of building a socialist harmonious society.[1] Education has always been the top priority of our party and enriching the country, improving the educational level of colleges and universities and cultivating the successors for the socialist construction. It is an important guarantee for our party to lead China to democracy and prosperity. Therefore, it should be in accordance with the scientific development concept of the actual meaning, and actively build a harmonious campus atmosphere.

Building a Harmonious Campus is to Meet the Needs of the Development of Globalization. At present, globalization has been constantly deepened, the international division of labor makes international trade and other economic exchanges more and more close, in order to win the competition in the context of globalization victory, we must pay attention to education. At present, 
the main problem faced by college students is employment difficulties, the key of which is that we are at the low end in the international division of labor chain. [2] We are more responsible for manufacturing while other channels are mostly occupied by foreign large enterprises and many jobs have been occupied by foreign college students. This requires us on one hand to vigorously support their own brands, increase research and compete for brand resources worldwide; on the other hand, we need to reform the university education training model, build a harmonious campus, and cultivate creative and enterprising students. [3]Harmonious campus is essential to cultivate capable college students with ideals and visions in the new situation.

Building a Harmonious Campus is the Need to Deepen the Reform of Higher Education and Promote the Comprehensive and Coordinated Development of Education. Constructing a harmonious campus is to safeguard and promote the reform of higher education. Education reform will inevitably encounter setbacks in the future, and harmonious campus can repair the problems in the process of reform of colleges and universities, which is mainly related to the essence of harmony, democracy and the rule of law, fairness and justice, honesty and fraternity, vitality, stability and order. Harmony between man and nature is the essence of building a socialist harmonious society, and the essence of the harmonious society, which requires the work must be carried out in accordance with the democratic way and the law form of management to ensure the legitimate rights and interests of students and teachers to establish a fair and just campus culture and create a good learning environment. Building a harmonious campus is an important driving force for the university to advance to the world. [4]It is an important guarantee for creating a soft environment of free, equal and enterprising colleges and universities.

\section{Problems Existing in Current Construction of Harmonious Campus}

The construction of harmonious campus is a long-term systematic project involving various aspects, and current, the outstanding problems mainly include the following aspects:

\section{Harmonious Campus Construction has been Constrained by the Concept Of Instrumental}

Values. Value-based tools refer to the educational administration of our country as a tool for teaching and instilling ideology and values. Taking moral education in colleges and universities as an example, at the international level, the degree of moral education in our country is unique. [5]The establishment of moral education curriculum and the identification of educational content shall be examined and approved by the Central Political Bureau, and then promulgated nationwide, and it shall be followed. This value-based tool as a guarantee of our party to cultivate the successor of socialism has practical significance and long-term value, but too high emphasis on the ideological transmission and indoctrination, is bound to students in the middle, produce resentment. Building a harmonious campus is to achieve the real unity of students and schools to achieve the unity of university education and national development, but simply rely on teaching and instilling to achieve the unity of ideology and the unity of university education is indeed a lack of realistic thinking. [6] The concept of instrumental value is an important obstacle to the construction of harmonious campus. It makes people use the market value to measure the gains and losses of the university policy, which is not conducive to the long-term development of colleges and universities, which is not conducive to the improvement of college students' quality.

The Construction of a Harmonious Campus has Been Influenced by the Interests of the Supremacy. Market economy emphasizes material interests and pursues the maximum profits, so it is easy to breed money worship and hedonism. University is a microcosm of a society, living in the wave of economic globalization, college students' main concern is employment. However, faced by the real environment, many college students can be influenced by utilitarian supremacy and money 
worship as well as hedonistic outlook on life. [7]They can wrongly apply the principle of equal exchange in market economy in morality and emotions, regard honorary status and fortune as the standard of life's happiness and take luxury and enjoyment as the greatest goal of life. Harmonious campus emphasizes that college students should establish a correct outlook on life and values, and through the construction of harmonious campus, a learning atmosphere emphasizing knowledge and quality is formed at colleges and universities, the spread and extension of some wrong ideas are prevented to make sure that college students can receive the best education at campus and have the highest moral values so as to become excellent talents with moth ability and morality for the long-term development of socialist market economy.

Harmonious Campus Construction has been Hampered by Moral Crisis. With the tide of globalization, the diversification of values and moral crisis and crisis of faith caused by social transition have proposed a serious challenge to the current construction of harmonious campus. First, moral judgment in social life is purely subjective and emotional; second, there is no basis for people's moral position, moral principles and moral values; third, virtue has retreated from the center of social life in the past to the brink of life. Therefore, in the contemporary moral changes, there is no absolute reasonable authority, leading to moral crisis. Morality is the basis of building a harmonious campus.[8] Without moral constraints, colleges will lose people's worship and the guarantee of constructing harmonious campus. College students are the hope of a country and future pillars. If there is no morality, China's future is precarious, so it is urgent to construct harmonious campus and advocate traditional virtues and socialist spiritual civilization.

\section{Effective Measures to Construct Harmonious Campus}

Insisting On Implementing the Scientific Concept of Development and Practice the Concept of Constructing Harmonious Campus According To the Requirements of Scientific Development Outlook. The first element in the outlook of scientific development is development, and to construct harmonious campus is to better promote the development of schools, accelerate the development of China's higher education and realize the set target of "revitalizing the country with science and education" strategy. In the construction of harmonious campus, colleges and universities need to take into account of all aspects and advance with the times. They should not only consider the big background of the times, but also guarantee the normal teaching and scientific research tasks at colleges and universities while taking into accounts of the interests of schools, teachers and students from the overall situation. [9]Meanwhile, backward systems and mechanisms should be timely eliminated. Colleges and universities are the forward position of thoughts, science and technology. They cannot take being conservative and closed as the umbrella of their peaceful mind, but they should have a sense of innovation and constantly push the university to a new height.

Establish the Correct Concept of the Development of Colleges And Universities, And Integrate the Globalization, Marketization, Diversification Into the Construction of A Harmonious Campus. The so-called harmony is that colleges and universities can share the benefits of globalization and fast, but also through the market to promote their own development, to achieve the orderly docking of the university and the market. At the same time, inclusive of different cultures, different beliefs to form a diversified cultural group. In order to build a harmonious campus, campus cannot be closed, colleges and universities should develop from the perspective of the times combined with international and domestic situation, straighten out the development of the times caused by some obstacles to the construction of a harmonious campus, actively looking for a breakthrough and adjusting disharmony.[10]

The Establishment of Incentive Mechanisms to Fully Mobilize the Enthusiasm of Teachers 
and Students to Strengthen the Campus Culture. Building a harmonious campus requires the participation of all teachers and students, we need to follow the concept of harmony to slowly change the disharmony of culture and thinking on campus. The school is our common home, and in order to build a harmonious campus, teachers are required to abandon their own personal desires and have the concept that I serve for everyone and everyone serves for me. [11]Colleges and universities need to establish incentive mechanisms to increase the campus culture and other ideological construction costs, and establish the concept of service for students and teachers, and organize more activities conducive to the construction of a harmonious campus, carry out a variety of campus cultural activities, focus on cultivating students' academic training and practical ability and establishing a healthy link with the society, so that students can understand the community and deepen their love of the society.

\section{Summary}

In short, the construction of harmonious campus is a long-term and arduous task that colleges and universities need to constantly explore according to their actual situations under the guidance of the outlook of scientific development while combining problems in development and carry out various investigations and researches. They should also summarize methods and measures to construct harmonious campus and push the construction of harmonious campus to a new height.

\section{References}

[1] D.Zhang, J.P.Wu:Campus Culture and Talent Training[M].Beijing: Tsinghua University Press, 2011(In Chinese)

[2] Y.Q.Liu,H.B.Shen:Combined College Operation and Construction of Campus Culture [J].Journal of Yangzhou University,2010（9）(In Chinese)

[3] M.Y.Pan:On the Quality of Popularized Higher Education [J].Jiangsu Higher Education, 2010(1) (In Chinese)

[4] Martin.Trow:Problems in the Transition from Elite Education to Mass Higher Education [J].Foreign Higher Education Information, 2014(1) (In Chinese)

[5] W.P.Cao:Several Educational Ideas to be Strengthened in Quality Education[J].China's Higher Education, 2013(6) (In Chinese)

[6] J.E.Zhou:Research and Practice of Talent Training Mode[M].Jiangxi : Jiangxi Higher Education Press, 2012(In Chinese)

[7] H.Wang:Constructing Harmonious Campus Culture under the New Situation[J]. Shanxi Youth, 2017 (2) (In Chinese)

[8] S.J.Liu:Strengthening the Construction of Teachers' Professional Ethics and Creating a Harmonious Campus Environment[J]. Weekly Academic Journal, 2017(1) (In Chinese)

[9] P.Yan:Constructing Harmonious Campus with Comprehensive Management[J]. Security, 2016 (1) (In Chinese)

[10]H.Hou:A Summary of the Research on Harmonious Campus Construction in Colleges and Universities[J]. Higher Education,2015 (10) (In Chinese)

[11]L.J.Wang:College Students' Participation in the Management of Colleges and Universities[D]. Northwest University, 2013. (In Chinese) 